\begin{tabular}{|c|l|}
\hline Title & Transition metal-catalyzed borylation of alkanes and arenes via C-H activation \\
\hline Author(s) & Ishiyama, Tatsuo; Miy aura, Norio \\
\hline Citation & $\begin{array}{l}\text { Journal of Organometallic Chemistry, 680(1-2), 3-11 } \\
\text { https://doi.org/10.1016/S0022-328X (03)00176-1 }\end{array}$ \\
\hline Issue Date & 2003-08-29 \\
\hline Doc URL & http://hdl.handle.net/2115/56230 \\
\hline Type & article (author version) \\
\hline File Information & (35) B-B + H-R \& H-Ar JOMC (Rev).pdf \\
\hline
\end{tabular}

Instructions for use 
Review for Special Issue "Frontiers in Boron Chemistry” Ed by Mike Mingos

\title{
Transition metal-catalyzed borylation of alkanes and arenes via $\mathrm{C}-\mathrm{H}$ activation
}

\author{
Tatsuo Ishiyama*, Norio Miyaura* \\ Division of Molecular Chemistry, Graduate School of Engineering, Hokkaido \\ University, Sapporo 060-8628, Japan
}

\begin{abstract}
Since 1999, direct borylation of hydrocarbons catalyzed by a transition metal complex has been extensively studied by several groups and has become an economical, efficient, elegant, and environmentally benign protocol for the synthesis of a variety of organoboron compounds. Re-, Rh-, Ir- and Pd-catalyzed C-H borylation of alkanes, arenes and benzylic positions of alkylarenes by bis(pinacolato)diboron or pinacolborane provide alkyl-, aryl-, heteroaryl- and benzylboron compounds, respectively. In this review, seminal early works and exciting recent developments in the area of direct borylation of hydrocarbons via $\mathrm{C}-\mathrm{H}$ activation are summarized.
\end{abstract}

Keywords: Transition metal complex; Bis(pinacolato)diboron; Pinacolborane; Hydrocarbon; Organoboron compound; C-H borylation

* Corresponding author. Fax: +81-11-7066562.

E-mail address: ishiyama@org-mc.eng.hokudai.ac.jp (T. Ishiyama). 


\section{Introduction}

Organoboron derivatives are an important class of compounds that have been utilized as synthetic intermediates [1-6], functional molecules [7-9], functional polymers [10], ${ }^{10} \mathrm{~B}$ carriers for neutron capture therapy [11], and biologically active compounds [12]. Traditional methods for their synthesis are based on the alkylation of trialkylborates with organomagnesium or -lithium reagents (transmetalation) $[1,13]$ or uncatalyzed addition of hydroboranes to unsaturated hydrocarbons (hydroboration) $[1,14]$. Although these methods are most common and convenient for large-scale preparations, the development of new methodology to solve difficulties in selectivity and efficiency of the traditional methods has provided a new class of organoboron compounds that can not be obtained by conventional protocols.

In the past 20 years, the use of transition metal catalysts has opened up many new possibilities in the area of borylation reactions. Catalytic hydroboration with (dialkoxo)boranes is an interesting strategy to realize different chemo-, regio-, and stereoselectivities relative to the uncatalyzed reaction [15]. The protocol has been successfully extended to the addition of B-B [15c,16], B-S [15c,17], B-Si [15c,18] or B-Sn [15c,19] reagents to alkenes or alkynes to synthesize organoboron compounds having an $\mathrm{R}_{2} \mathrm{~B}, \mathrm{RS}, \mathrm{R}_{3} \mathrm{Si}$ or $\mathrm{R}_{3} \mathrm{Sn}$ group at the $\beta$-carbon of alkyl-, vinyl- and allylboron derivatives. Successful cross-coupling of B-B $[15 c, 16]$ or B-H $[15 c, 20]$ reagents with aryl, vinyl, allyl and benzyl halides or triflates has provided a one-step procedure for the synthesis of organoboron compounds from organic electrophiles. Because of the 
availability of various electrophiles and mild reaction conditions, this method has allowed convenient access to organoboron compounds that have a variety of functional groups. In most of these reactions, it is widely recognized that the catalytic cycles involve (boryl)metal species as key intermediates.

On the other hand, increasing attention has been focused on transition metal-catalyzed activation and functionalization of unreactive $\mathrm{C}-\mathrm{H}$ bonds of hydrocarbons, which are both achieved in a single preparative step, thus combining economy, efficiency, elegance, and environmental benignity [21]. An extension of this methodology to $\mathrm{C}-\mathrm{H}$ borylation would be of significant value for synthesis of organoboron compounds. Some key steps in putative catalytic cycles have recently been established by several groups via stoichiometric $\mathrm{C}-\mathrm{H}$ borylation of alkanes, arenes and alkenes with (boryl)metal complexes $[22,23]$. Those discoveries were followed by the rapid development of catalytic processes for direct borylation of hydrocarbons with bis $\left(\right.$ pinacolato)diboron $\left(\operatorname{pin}_{2} \mathrm{~B}_{2}\right.$, pin $\left.=\mathrm{Me}_{4} \mathrm{C}_{2} \mathrm{O}_{2}\right)$ or pinacolborane $(\mathrm{pinBH})$. Most of the reactions demonstrated the efficiency of $\operatorname{pin}_{2} \mathrm{~B}_{2}$; however, analogous reactions could also be carried out with pinBH, which is more economical.

\section{Aliphatic C-H borylation}

\subsection{Re-catalyzed photochemical reaction of alkanes}

$\mathrm{C}-\mathrm{H}$ borylation of alkanes was first demonstrated by Hartwig and co-workers using photochemical activation of $\mathrm{Cp}^{*} \operatorname{Re}(\mathrm{CO})_{3}$ (Scheme 1) [24]. With irradiation from a 450-watt medium-pressure Hanovia mercury arc lamp, reaction of $\operatorname{pin}_{2} B_{2}$ in alkane in 
the presence of $\mathrm{Cp}^{*} \operatorname{Re}(\mathrm{CO})_{3}(2.4-5.0 \mathrm{~mol} \%)$ and $\mathrm{CO}(2 \mathrm{~atm})$ produced the corresponding alkylboronates. Although pinBH thus generated did not participate in the catalytic cycle, all reactions were remarkable in their regiospecificity for the functionalization of primary carbons.

$<<$ Scheme 1 >>

Photochemical reaction of $n$-pentane with $\mathrm{Cp} * \operatorname{Re}(\mathrm{CO})_{2}(\mathrm{Bpin})_{2}$, prepared from $\mathrm{Cp} * \operatorname{Re}(\mathrm{CO})_{3}$ and $\operatorname{pin}_{2} \mathrm{~B}_{2}$, led to the regiospecific formation of 1-borylpentane in quantitative yield (Scheme 2). Thus, the catalytic cycle involves oxidative addition of $\operatorname{pin}_{2} \mathrm{~B}_{2}$ to $\mathrm{Cp} * \operatorname{Re}(\mathrm{CO})_{3}(\mathbf{1})$ with photochemical dissociation of $\mathrm{CO}, \mathrm{C}-\mathrm{H}$ activation by $\mathrm{Cp} * \operatorname{Re}(\mathrm{CO})_{2}(\mathrm{Bpin})_{2}(2)$ with dissociation of $\mathrm{CO}$, and finally reductive elimination of an alkylboronate with association of CO (Scheme 3) [24]. The interaction required for C-H activation of alkane with $\mathrm{Cp} * \operatorname{Re}(\mathrm{CO})_{2}(\mathrm{Bpin})_{2} 2$ has not yet been determined; however, higher reactivity of primary over secondary $\mathrm{C}-\mathrm{H}$ bonds has been reported in both oxidative addition and $\sigma$-bond metathesis processes. The isomerization of a sec-alkyl group in $\mathrm{Cp} * \operatorname{Re}(\mathrm{H})(\mathrm{R})(\mathrm{CO})(\mathrm{Bpin})_{2}(3)$ to an $n$-alkyl isomer before reductive elimination of pinB-R is another probable process that is often observed in metal-catalyzed hydroboration of internal alkenes [15c].

$<<$ Schemes 2 and $3>>$

\subsection{Rh-catalyzed reaction of alkanes}

A practical method for direct borylation of non-activated alkanes by Rh-catalyzed reactions was reported by Hartwig (Scheme 4) [25]. Among the catalysts employed, which included $\mathrm{Cp}^{*} \operatorname{IrH}_{4}, \quad \mathrm{Cp} * \operatorname{Ir}\left(\mathrm{C}_{2} \mathrm{H}_{4}\right)_{2}, \quad \mathrm{Cp} * \mathrm{Rh}\left(\mathrm{C}_{2} \mathrm{H}_{4}\right)_{2}, \quad \mathrm{Cp} * \mathrm{Rh}\left(\mathrm{C}_{2} \mathrm{H}_{3} \mathrm{SiMe}_{3}\right)_{2}$, 
$\mathrm{Cp} * \mathrm{Rh}(\mathrm{H})_{2}\left(\mathrm{SiEt}_{3}\right)_{2}$ and $\mathrm{Cp} * \mathrm{Rh}\left(\eta^{4}-\mathrm{C}_{6} \mathrm{Me}_{6}\right)$, the hexamethylbenzene complex showed greater long-term activity with a low catalyst loading. Again, alkanes regiospecifically reacted at the terminal carbon with $\operatorname{pin}_{2} \mathrm{~B}_{2}$ at $150{ }^{\circ} \mathrm{C}$. In the presence of $\mathrm{Cp} * \mathrm{Rh}\left(\eta^{4}-\mathrm{C}_{6} \mathrm{Me}_{6}\right)$ (4.0-6.0 mol\%), 1 equiv of $\operatorname{pin}_{2} \mathrm{~B}_{2}$ afforded almost 2 equivs of 1-borylalkanes, thus indicating participation of pinBH in the catalytic cycle. Indeed, pinBH in $n$-octane gave pinacol $n$-octylboronate in $65 \%$ yield (Scheme 5 ).

$<<$ Schemes 4 and $5>>$

${ }^{11} \mathrm{~B}$ NMR spectra of reactions of $\operatorname{pin}_{2} \mathrm{~B}_{2}$ with $\mathrm{Cp} * \mathrm{Rh}\left(\eta^{4}-\mathrm{C}_{6} \mathrm{Me}_{6}\right)$ in $n$-octane at high catalyst loadings exhibited a resonance at $40 \mathrm{ppm}$, which is identical with that of trans- $\left[\mathrm{Cp} * \mathrm{Rh}(\mathrm{H})_{2}(\mathrm{Bpin})_{2}\right]$ prepared from trans- $\left[\mathrm{Cp} * \mathrm{Rh}(\mathrm{H})_{2}\left(\mathrm{SiEt}_{3}\right)_{2}\right]$ and $\operatorname{pin}_{2} \mathrm{~B}_{2}(\mathrm{Scheme}$ 6). The thus obtained trans-[Cp* $\left.\mathrm{Rh}(\mathrm{H})_{2}(\mathrm{Bpin})_{2}\right]$ reacted with $n$-octane, giving 2 equivs of 1-boryloctane in $90 \%$ yield, thus suggesting that trans- $\left[\mathrm{Cp} * \mathrm{Rh}(\mathrm{H})_{2}(\mathrm{Bpin})_{2}\right]$ is chemically and kinetically competent to be an intermediate in the catalytic process. The mechanism has been suggested to be an $\mathrm{Rh}(\mathrm{III})-\mathrm{Rh}(\mathrm{V})$ cycle involving oxidative addition of $\operatorname{pin}_{2} B_{2}$ or pinBH to a $\mathrm{Rh}(\mathrm{III})$ complex (4), reductive elimination of $\mathrm{H}_{2}$ or pinBH to form an $\mathrm{Rh}(\mathrm{III})$ species (5), oxidative addition of an alkane to the $\mathrm{Rh}(\mathrm{III})$ complex $\mathbf{5}$, and reductive elimination of a 1-borylalkane from an $\mathrm{Rh}(\mathrm{V})$ intermediate $(\mathbf{6})$ to regenerate the $\mathrm{Rh}(\mathrm{III})$ species 4 (Scheme 7) [25]. These proposed processes have been supported by the results of recent theoretical studies by Miyamoto and co-workers [26]. Unusual thermodynamic properties of boron reagents provide the driving force for the overall process. In the initial stage of the reaction between $\mathrm{R}-\mathrm{H}$ and $\operatorname{pin}_{2} \mathrm{~B}_{2}$, the $\mathrm{B}-\mathrm{C}$ (112 kcal/mol) and B-H (111 kcal/mol) bonds formed are $21 \mathrm{kcal} / \mathrm{mol}$ stronger than the B-B $(104 \mathrm{kcal} / \mathrm{mol})$ and C-H $(98 \mathrm{kcal} / \mathrm{mol})$ bonds that are broken. The second stage of the reaction between $\mathrm{R}-\mathrm{H}$ and pinBH is also slightly exothermic since the formation of 
B-C and $\mathrm{H}_{2}(104 \mathrm{kcal} / \mathrm{mol})$ are $7 \mathrm{kcal} / \mathrm{mol}$ stronger than the $\mathrm{B}-\mathrm{H}$ and $\mathrm{C}-\mathrm{H}$ bonds that are broken.

$<<$ Schemes 6 and $7>>$

\section{Aromatic C-H borylation}

\subsection{Ir-catalyzed reaction of arenes}

The first example of aromatic C-H borylation with Ir complexes was reported by Marder and co-workers [22]. During preparation of $\operatorname{Ir}\left(\eta^{6}-\mathrm{MeC}_{6} \mathrm{H}_{5}\right)(\mathrm{Bcat})_{3}$ from $\operatorname{Ir}\left(\eta^{5}-\mathrm{C}_{9} \mathrm{H}_{7}\right)(\mathrm{COD})$ and catecholborane $\left(\mathrm{catBH}\right.$, cat $\left.=\mathrm{C}_{6} \mathrm{H}_{4} \mathrm{O}_{2}\right)$ in toluene, a borylated product of the solvent was found in the filtrate, though this finding was not extended to a catalytic process. A catalytic reaction was first demonstrated by Smith and co-workers, who reported that a combination of a $\mathrm{Cp}^{*} \mathrm{Ir}$ complex and an electron-donating alkylphosphine such as $\mathrm{PMe}_{3}$ is effective for aromatic $\mathrm{C}-\mathrm{H}$ borylation by pinBH. (Scheme 8) [27]. Further studies resulted in significant improvement in catalyst efficiency. A maximum turnover number (4500 TON) was achieved at $150{ }^{\circ} \mathrm{C}$ when $\operatorname{Ir}\left(\eta^{5}-\mathrm{C}_{9} \mathrm{H}_{7}\right)(\mathrm{COD})$ and a bidentate alkylphosphine such as dmpe (1,2-bis(dimethylphosphino)ethane) were used at $150{ }^{\circ} \mathrm{C}$ in a sealed ampule (Scheme 9) [28]. The orientation was kinetically determined, thus giving statistical meta/para isomers (ca. 2/1) for monosubstituted arenes. Borylation selectively occurred at the common meta-carbon for 1,3-disubstituted arenes, such as 1,3-dichlorobenzene and methyl 3-chlorobenzoate, since the reaction was more sensitive to steric hindrance than 
electronic effects of the substituents.

$<<$ Schemes 8 and 9>>

Alternatively, a strongly electron-donating 2,2'-bipyridine (bpy) ligand [29] has a significantly higher efficiency than do alkylphosphine ligands for Ir-catalyzed aromatic $\mathrm{C}-\mathrm{H}$ borylation. The ligand was unexpectedly found during our catalyst screening for dehydrogenative coupling of pinBH. Heating a mixture of $[\mathrm{IrCl}(\mathrm{COD})]_{2}$, bpy and pinBH in toluene led to borylation of the solvent, which is a serendipity similar to the incident happened to Marder in 1993 [22]. As a result, an Ir complex generated from commercially available $1 / 2[\operatorname{IrCl}(\mathrm{COD})]_{2}$ and bpy was found to be an excellent catalyst for aromatic $\mathrm{C}-\mathrm{H}$ borylation by $\operatorname{pin}_{2} \mathrm{~B}_{2}$, which exhibited high activity even at $80{ }^{\circ} \mathrm{C}$ (Scheme 10) [30]. Formation of almost 2 equivs of borylarenes from 1 equiv of $\operatorname{pin}_{2} B_{2}$ indicated that the optimized catalyst system is also effective for the borylation of arenes by pinBH. Indeed, the reaction of pinBH in benzene produced borylbenzene in high yield (Scheme 11). The reaction was found to be suitable for arenes possessing various functional groups such as $\mathrm{OMe}, \mathrm{Br}, \mathrm{Cl}$, and $\mathrm{CF}_{3}$ or benzylic $\mathrm{C}-\mathrm{H}$ bonds because the borylation at the $\mathrm{C}$-halogen bonds [31] or benzylic $\mathrm{C}-\mathrm{H}$ bonds [32] was significantly slower than that at aromatic $\mathrm{C}-\mathrm{H}$ bonds. Both electron-rich and electron-deficient monosubstituted arenes underwent smooth borylation, whereas these reactions resulted in a mixture of meta and para products in statistical ratios (ca. 2:1). Although the reaction of trifluoromethylbenzene was 6-times faster than that of anisole [33], the electronic properties of the substituents did not have significant influences on regioselectivities [23a]. On the other hand, borylation at the ortho position was not observed because of the sensitivity of the catalyst to steric hindrance, thus giving a single isomer for disubstituted arenes. Both 1,2-, and 1,4-disubstituted arenes bearing 
identical substituents yielded the corresponding borylarenes as single isomers. The borylation of 1,3-disubstituted arenes occurred at the common meta position; therefore, regioisomerically pure products were obtained even for two distinct substituents on the arenes. A slightly modified $\mathrm{Ir}$ catalyst consisting of $1 / 2\left[\operatorname{IrCl}(\mathrm{COE})_{2}\right]_{2}$ and 4,4'-di-tert-butyl-2,2'-bipyridine (dtbpy) achieved a maximum turnover number (8000 TON) (Scheme 12).

$<<$ Schemes 10, 11 and 12>>

Mechanistic studies by Hartwig's group resulted in isolation of an active intermediate for borylation. ${ }^{1} \mathrm{H}$ NMR spectroscopy for the reactions of $\operatorname{pin}_{2} \mathrm{~B}_{2}$ in benzene at a high catalyst loading of $1 / 2[\operatorname{IrCl}(\mathrm{COD})]_{2}+\mathrm{dtbpy}$ showed the formation of a dtbpy-ligated tris(boryl)Ir(III) complex that was identical to $\operatorname{Ir}(\mathrm{dtbpy})(\mathrm{COE})(\mathrm{Bpin})_{3}$ (Scheme 13). When $\operatorname{Ir}(\mathrm{dtbpy})(\mathrm{COE})(\mathrm{Bpin})_{3}$ was dissolved in $\mathrm{C}_{6} \mathrm{D}_{6}$ at room temperature, 3 equivs of borylbenzene $(80 \%)$ were produced instantaneously. Thus, $\operatorname{Ir}(\mathrm{dtbpy})(\mathrm{COE})(\text { Bpin })_{3}$ was shown to be chemically and kinetically competent to be an intermediate in the catalytic process [30], as was found in related reactions of tris(boryl)Ir(III) complexes [22,28]. Although a mechanism of the overall catalytic process has not yet been elucidated, the reaction may proceed through an $\operatorname{Ir}(\mathrm{III})-\operatorname{Ir}(\mathrm{V})$ cycle analogous to that proposed for $\mathrm{Rh}(\mathrm{I})$-catalyzed borylation of alkanes (Scheme 14). Generation of a tris(boryl) $\operatorname{Ir}(\mathrm{III})$ intermediate $(\mathbf{8})$ by the reaction of $\operatorname{pin}_{2} \mathrm{~B}_{2}$ with an $\operatorname{Ir}(\mathrm{I})$ complex (7), oxidative addition of an arene to yield an $\operatorname{Ir}(\mathrm{V})$ species $(\mathbf{9})$, and reductive elimination of a borylarene to give a bis(boryl)Ir(III) hydride complex (10) can be followed by oxidative addition of $\operatorname{pin}_{2} B_{2}$ and reductive elimination of pinBH to regenerate the tris(boryl) $\operatorname{Ir}(\mathrm{III})$ intermediate 8. These proposed processes have been supported by the results of recent theoretical studies by Sakaki and co-workers [34]. The 
catalytic reaction of $\operatorname{pin}_{2} \mathrm{~B}_{2}$ in benzene at $80{ }^{\circ} \mathrm{C}$ revealed a two-step process: fast borylation by $\operatorname{pin}_{2} \mathrm{~B}_{2}$ followed by slow borylation by pinBH. Thus, the generation of a tris(boryl) $\operatorname{Ir}(\mathrm{V})$ dihydride complex (11) and $\mathrm{H}_{2}$ may occur after consumption of $\operatorname{pin}_{2} \mathrm{~B}_{2}$ [28].

$<<$ Schemes 13 and 14>>

\subsection{Ir-catalyzed reaction of heteroarenes}

Under analogous conditions used for arenes, the reactions of $\operatorname{pin}_{2} B_{2}$ in heteroarenes in the presence of a $1 / 2[\operatorname{IrCl}(\mathrm{COD})]_{2}+$ bpy catalyst did not yield any borylated products, probably due to coordination of the heteroatom to the Ir metal center strongly retarding the formation of an unsaturated Ir species active for oxidative addition of $\operatorname{pin}_{2} B_{2}$ or heteroarenes [35]. The use of octane as a solvent to reduce the concentration of substrates $\left(\operatorname{pin}_{2} \mathrm{~B}_{2}\right.$ :heteroarene $\left.=1: 4-10\right)$ and the use of dtbpy as a ligand to increase the solubility of Ir complexes in octane were found to be effective for heteroarenes (Scheme 15) [36]. Five-membered heteroarenes such as pyrrole, furan, thiophene and their benzo-fused derivatives were selectively borylated at the 2-position [37]. The reactions of unsubstituted pyrrole, furan and thiophene resulted in slightly lower yields than those of benzo-fused derivatives because they were accompanied by 2,5-bis(boryl)heteroarenes in a range of 5 to $10 \%$. The regiochemistry can be made to vary by steric hindrance of substituents to selectively synthesize 3-borylated products for 1-triisopropylsilylpyrrole and -indole [38]. 2,5-Bis(boryl)pyrrole, -furan and -thiophene are useful intermediates for the synthesis of poly(arylenes), including those for use in electroluminescence devices [39]. These compounds were obtained from an 
equimolar amount of heteroarenes and $\operatorname{pin}_{2} \mathrm{~B}_{2}$ (Scheme 16).

$<<$ Schemes 15 and 16>>

Six-membered heteroarenes showed significantly lower reactivity and different regioselectivity than those of five-membered compounds. Quinoline selectively gave 3-borylquinoline, whereas pyridine resulted in a mixture of 3- and 4-borylpyridine in a ratio of 67:33 (Scheme 17). Transition metal complexes are known to react at the 2-position of heteroarenes via oxidative addition of the $\mathrm{C}-\mathrm{H}$ bond [37]. Thus, borylation at the $\alpha$-carbon can be an energetically favorable process; however, the regioselectivities observed for pyridine and quinoline were different from those of five-membered heteroarenes. Since pyridine derivatives have exceptionally strong coordination ability for Lewis acids, the Ir metal or the B atom binds reversibly to the basic nitrogen. The coordination may further activate the pyridine and quinoline rings for oxidative addition and block the borylation at the $\alpha$-carbon. (Scheme 18). Such borylation at the $\gamma$-position of 2,6-dichloropyridine was reported by Smith (Scheme 19) [28]. The substituents will reduce such difficulties associated with the coordinating ability of heteroatoms.

$<<$ Schemes 17, 18 and 19>>

3.3. Ir-catalyzed stoichiometric reaction of arenes and heteroarenes at room temperature

Although an Ir complex generated from $1 / 2[\operatorname{IrCl}(\mathrm{COD})]_{2}$ and bpy or dtbpy catalyzes aromatic $\mathrm{C}-\mathrm{H}$ borylation of arenes or heteroarenes by $\operatorname{pin}_{2} \mathrm{~B}_{2}$ at $80{ }^{\circ} \mathrm{C}[30,36]$, reactions at room temperature with a stoichiometric amount of arenes or heteroarenes in 
an inert solvent would be desirable for solid, expensive, or thermally unstable substrates. It was recently found that $\operatorname{pin}_{2} B_{2}$ smoothly reacts with a stoichiometric amount of arenes or heteroarenes in hexane at room temperature when an Ir catalyst (3 mol\%) was prepared from $1 / 2[\operatorname{Ir}(\mathrm{OMe})(\mathrm{COD})]_{2}$ and dtbpy (Scheme 20) [40]. The reactions were tolerated by a wide variety of functionalities, such as $\mathrm{MeO}, \mathrm{I}, \mathrm{Br}, \mathrm{Cl}, \mathrm{CO}_{2} \mathrm{Me}, \mathrm{CN}$, and $\mathrm{CF}_{3}$ groups. The regioselectivities were almost the same as those observed for $1 / 2[\operatorname{IrCl}(\mathrm{COD})]_{2}+$ bpy or $+\mathrm{dtbpy}$.

\section{$<<$ Scheme 20>>}

The desired tris(boryl)Ir(III) complex discussed in Schemes 13 and 14 [22,28,30] can be generated by oxidative addition of $\operatorname{pin}_{2} \mathrm{~B}_{2}$ to the mono(boryl) $\operatorname{Ir}(\mathrm{I})$ complex. Thus, smooth formation of the mono(boryl) $\operatorname{Ir}(\mathrm{I})$ complex [Ir](Bpin) (13) may be critical for in situ generation of the active tris(boryl) $\operatorname{Ir}(\mathrm{III})$ species $[\operatorname{Ir}](\mathrm{Bpin})_{3}(\mathbf{1 4})$ for the borylation (Scheme 21). The (methoxo) $\operatorname{Ir}(\mathrm{I})$ complex $[\mathrm{Ir}](\mathrm{OMe})(\mathbf{1 2})$ was found to be a better catalyst precursor than $[\mathrm{Ir}] \mathrm{Cl}$ complex since it smoothly provided the mono(boryl) complex 13 via reaction with $\operatorname{pin}_{2} \mathrm{~B}_{2}$. The Ir precursor was designed on the basis of our previous observations that (alkoxo)- and (hydroxo)Pd(II) complexes and (hydroxo) $\mathrm{Rh}(\mathrm{I})$ complexes easily undergo transmetalation with various boron compounds, including $\operatorname{pin}_{2} \mathrm{~B}_{2}$, whereas $\mathrm{Pd}(\mathrm{II})$ and $\mathrm{Rh}(\mathrm{I})$ halides are inert under neutral conditions $[2,16]$. High reactivity of $\mathrm{M}(\mathrm{OR})$ complexes for transmetalation with boron compounds can be attributed to both the high basicity of the $\mathrm{M}(\mathrm{OR})$ species and the high oxophilicity of the boron center.

\section{$<<$ Scheme 21 $>>$}

Most recently, it has been found that the protocol could be extended to the stoichiometric borylation by pinBH at room temperature (Scheme 22) [41]. This 
reaction is a practical method for large-scale preparation because of the low cost of pinBH and the compatibility of reducible functional groups at room temperature.

$<<$ Scheme 22>>

\subsection{Re-catalyzed photochemical reaction of arenes}

Hartwig carried out borylation of benzene by $\operatorname{pin}_{2} B_{2}$ under the same conditions as those used for aliphatic C-H borylation (Scheme 23) [24]. The reaction may proceed through a mechanism similar to that postulated for aliphatic $\mathrm{C}-\mathrm{H}$ borylation.

$<<$ Scheme 23>>

\subsection{Rh-catalyzed reaction of arenes and heteroarenes}

Under conditions similar to those used for aliphatic $\mathrm{C}-\mathrm{H}$ borylation by Hartwig, $\mathrm{Rh}$ complexes catalyzed the borylation of benzene by $\operatorname{pin}_{2} \mathrm{~B}_{2}$ (Scheme 24) [25]. $\mathrm{Cp} * \mathrm{Rh}\left(\eta^{4}-\mathrm{C}_{6} \mathrm{Me}_{6}\right)$, which extrudes unreactive hexamethylbenzene, was found to be the best Rh catalyst, giving a $92 \%$ yield after $2.5 \mathrm{~h}$ with $5 \mathrm{~mol} \%$ catalyst loading and an $82 \%$ yield (328 TON) with $0.5 \mathrm{~mol} \%$ loading at $150{ }^{\circ} \mathrm{C}$.

$<<$ Scheme 24>>

Aromatic borylation by pinBH with Hartwig's catalyst $\mathrm{Cp} * \mathrm{Rh}\left(\eta^{4}-\mathrm{C}_{6} \mathrm{Me}_{6}\right)$ was amply demonstrated by Smith (Scheme 25) [38,42]. In a cyclohexane solvent at $150{ }^{\circ} \mathrm{C}$ in a sealed ampule, 1,3-disubstituted arenes were selectively borylated at the 5-position and 1,2-disubstituted arenes were selectively borylated at the 4-position. 1-Triisopropylsilylpyrrole selectively provided a 3-borylated compound in $81 \%$ yield. 
Although Ir catalysts such as $\mathrm{Cp} * \operatorname{Ir}\left(\mathrm{PMe}_{3}\right)(\mathrm{H})(\mathrm{Bpin})$ were more selective than were Rh catalysts for competitive borylation at aromatic $\mathrm{C}-\mathrm{H}$ and benzylic $\mathrm{C}-\mathrm{H}$ bonds for alkylarenes or at aromatic $\mathrm{C}-\mathrm{H}$ and aromatic and aliphatic $\mathrm{C}$-halogen bonds for haloarenes, $\mathrm{Cp} * \mathrm{Rh}\left(\eta^{4}-\mathrm{C}_{6} \mathrm{Me}_{6}\right)$ showed significantly higher turnover numbers than did the corresponding Ir catalysts.

\section{$<<$ Scheme 25>>}

Aromatic C-H borylation by pinBH with an Rh catalyst was also briefly studied by Marder (Scheme 26) [43]. The reaction of $\mathrm{pinBH}$ in benzene at $140{ }^{\circ} \mathrm{C}$ in the presence of $\operatorname{RhCl}\left\{\mathrm{P}(i-\mathrm{Pr})_{3}\right\}_{2}\left(\mathrm{~N}_{2}\right)(0.3 \mathrm{~mol} \%)$ afforded borylbenzene in $67 \%$ yield. Although the catalyst gave benzylic boronates for alkylbenzenes, $\left[\mathrm{Cp}^{*} \mathrm{RhCl}_{2}\right]_{2}$ was found to be selective for aromatic $\mathrm{C}-\mathrm{H}$ borylation.

$<<$ Scheme 26>>

\section{Benzylic C-H borylation}

\subsection{Rh-catalyzed reaction of alkylbenzenes}

Selective benzylic C-H borylation was first established by Marder (Scheme 27) [43]. The reaction of pinBH in toluene in the presence of $\operatorname{RhCl}\left\{\mathrm{P}(i-\mathrm{Pr})_{3}\right\}_{2}\left(\mathrm{~N}_{2}\right)(1 \mathrm{~mol} \%)$ at $140{ }^{\circ} \mathrm{C}$ gave (borylmethyl)benzene and \{bis(boryl)methyl $\}$ benzene in $69 \%$ and $7 \%$ yield together with several products arising from aromatic $\mathrm{C}-\mathrm{H}$ borylation (ca. 15\%). $p$-Xylene and mesitylene also produced the corresponding benzylboronates. A mechanism was proposed involving formation of $\mathrm{Rh}(\mathrm{Bpin})$ from $\mathrm{Rh}(\mathrm{H})$ and $\operatorname{pinBH}$, oxidative addition of a benzylic $\mathrm{C}-\mathrm{H}$ bond of toluene giving a $\eta^{3}$-benzyl complex, and 
finally reductive elimination of $\operatorname{pinBCH}_{2} \mathrm{Ph}$ to regenerate the $\mathrm{Rh}(\mathrm{H})$. The results have suggested that there is a difference between selectivities of oxidative addition of $\mathrm{Rh}(\mathrm{I})$ and $\mathrm{Rh}(\mathrm{III})$ complexes. Oxidative addition of benzylic $\mathrm{C}-\mathrm{H}$ bonds giving a $\eta^{3}$-benzyl complex predominates for a mono(boryl)Rh(I) complex, whereas a tris(boryl)Rh(III) species activates the aromatic $\mathrm{C}-\mathrm{H}$ bond rather than the weaker benzylic $\mathrm{C}-\mathrm{H}$ bonds $[38,42]$. It is interesting to note that catalytic dehydrogenative coupling of pinBH to $\operatorname{pin}_{2} B_{2}$ was observed with the present catalyst system.

\subsection{Pd-catalyzed reaction of alkylbenzenes}

$\mathrm{Pd} / \mathrm{C}$ was found to catalyze the benzylic $\mathrm{C}-\mathrm{H}$ borylation of alkylbenzenes by $\operatorname{pin}_{2} B_{2}$ (Scheme 28) [44]. The reaction of $\operatorname{pin}_{2} B_{2}$ in toluene proceeded at $100{ }^{\circ} \mathrm{C}$ to afford (borylmethyl)benzene in $74 \%$ yield as the sole product. Xylenes and mesitylene were all viable substrates; however, ethylbenzene resulted in a 3:1 mixture of benzylboron and homobenzylboron derivatives (Scheme 29). The formation of the latter product can be attributed to positional isomerization of (benzyl)Pd intermediates to (homobenzyl)Pd species via a $\beta$-hydride elimination-insertion process [45]. The catalytic reaction of $\operatorname{pin}_{2} B_{2}$ with toluene revealed a two-step process: fast borylation by $\operatorname{pin}_{2} B_{2}$ followed by slow borylation by pinBH. Indeed, pinBH borylated toluene with $52 \%$ yield (Scheme 30$)$.

$<<$ Schemes 28, 29 and 30>>

\section{Acknowledgments}

Aromatic $\mathrm{C}-\mathrm{H}$ borylation catalyzed by $\mathrm{Ir}+\mathrm{bpy}$ complexes was carried out by a 
joint project in collaboration with Hartwig's group. We are greatly indebted to Professor

John F. Hartwig for his contributions to the elucidation of the mechanism and helpful discussion. This work was supported by Grant-in-Aid for Scientific Research on Priority Areas (No. 14078101, "Reaction Control of Dynamic Complexes") from Ministry of Education, Culture, Sports, Science and Technology, Japan. T.I. thanks Itoh Science Foundation for support of a part of his work.

\section{References}

[1] General reviews, see: (a) A. Pelter, K. Smith, H.C. Brown, Borane Reagents, Academic Press, London, 1988;

(b) M. Vaultier, B. Carboni, in: E.W. Abel, F.G.A. Stone, G. Wilkinson (Eds.), Comprehensive Organometallic Chemistry II, vol. 11, Pergamon Press, Oxford, 1995, p. 191;

(c) D.S. Matteson, Stereodirected Synthesis with Organoboranes, Springer, Berlin, 1995.

[2] Reviews for Pd-catalyzed cross-coupling with organic electrophiles, see: (a) N. Miyaura, A. Suzuki, Chem. Rev. 95 (1995) 2457;

(b) A. Suzuki, in: F. Diederich, P.J. Stang (Eds.), Metal-Catalyzed Cross-Coupling Reactions, Wiley-VCH, Weinheim, 1998, p. 49;

(c) N. Miyaura, in: L.S. Liebeskind (Ed.), Advances in Metal-Organic Chemistry, vol. 6, JAI Press, London, 1998, p. 187;

(d) N. Miyaura, Top. Curr. Chem. 219 (2002) 11.

[3] Reviews for Rh-catalyzed addition to carbonyl compounds, see: (a) N. Miyaura, 
in: P.V. Ramachandran, H.C. Brown (Eds.), ACS Symposium Series 783:

Organoboranes for Syntheses (Chapter 7), American Chemical Society, Washington DC, 2001;

(b) T. Hayashi, Synlett (2001) 879.

[4] Reviews for Matteson homologation, see: (a) D.S. Matteson, Tetrahedron 54 (1998) 10555;

(b) D.S. Matteson, J. Organomet. Chem. 581 (1999) 51.

[5] A review for Petasis reaction, see: N.A. Petasis, I.A. Zavialov, in: Advances in Boron Chemistry, The Royal Society of Chemistry, Cambridge, 1997, p. 179.

[6] Cu-promoted or -catalyzed N-, O-, or S-arylation, see: (a) D.M.T. Chan, K.L. Monaco, R.-P. Wang, M.P. Winters, Tetrahedron Lett. 39 (1998) 2933;

(b) D.A. Evans, J.L. Katz, T.R. West, Tetrahedron Lett. 39 (1998) 2937;

(c) P.S. Herradura, K.A. Pendola, R.K. Guy, Org. Lett. 2 (2000) 2019.

[7] Templates for C-C bond formation, see: (a) J.G. de Vries, S.A. Hubbard, J. Chem. Soc., Chem. Commun. (1988) 1172;

(b) G. Wulff, P. Birnbrich, A. Hansen, Angew. Chem. 100 (1988) 1197;

(c) J.D. Chambers, J. Crawford, H.W.R. Williams, C. Dufresne, J. Scheigetz, M.A. Bernstein, C.K. Lau, Can. J. Chem. 70 (1992) 1717.

[8] Reviews for Lewis acid catalysts, see: (a) K. Ishihara, H. Yamamoto, Eur. J. Org. Chem. (1999) 527;

(b) K. Maruoka, T. Ooi, Chem. Eur. J. 5 (1999) 829.

[9] Reviews for Sugar receptors, see: (a) J.H. Hartley, T.D. James, C.J. Ward, J. Chem. Soc., Perkin Trans. 1 (2000) 3155;

(b) S. Shinkai, M. Ikeda, A. Sugasaki, M. Takeuchi, Acc. Chem. Res. 34 (2001) 
494;

(c) M. Takeuchi, M. Ikeda, A. Sugasaki, S. Shinkai, Acc. Chem. Res. 34 (2001) 865.

[10] Polymers, see: (a) N. Matsumi, K. Naka, Y. Chujo, J. Am. Chem. Soc. 120 (1998) 5112;

(b) N. Matsumi, K. Naka, Y. Chujo, J. Am. Chem. Soc. 120 (1998) 10776;

(c) A review, see: C.D. Entwistle, T.B. Marder, Angew. Chem., Int. Ed. 41 (2002) 2927.

[11] Reviews for boron neutron capture therapy, see: (a) A.H. Soloway, W. Tjarks, B.A. Barnum, F.-G. Rong, R.F. Barth, I.M. Codogni, J.G. Wilson, Chem. Rev. 98 (1998) 1515;

(b) M.F. Hawthorne, A. Maderna, Chem. Rev. 99 (1999) 3421;

(c) W. Tjarks, J. Organomet. Chem. 614-615 (2000) 37.

[12] Biological activities, see: (a) J.A. Powell, M.A. Carrasco, D.S. Adams, B. Drouet, J. Rios, M. Muller, M. Estrada, E. Jaimovich, J. Cell Sci. 114 (2001) 3673 ;

(b) K. Kaur, R.F. Pratt, Biochemistry 40 (2001) 4610;

(c) L.M.; Broad, F.-J. Braun, J.-P. Lievremont, G.S.J. Bird, T. Kurosaki, J.W. Putney Jr, J. Biol. Chem. 276 (2001) 15945.

[13] A review, see: A.N. Nesmeyanov, R.A. Sokolik, Methods of Elemento-Organic Chemistry, vol. 1, North-Holland, Amsterdam, 1967.

[14] Reviews, see: (a) H.C. Brown, Hydroboration, Benjamin, New York, 1962;

(b) M. Zaidlewicz, in: G. Wilkinson, F.G.A. Stone, E.W. Abel (Eds.), Comprehensive Organometallic Chemistry, vol. 7, Pergamon Press, Oxford, 
1982, p. 143;

(c) K. Smith, A. Pelter, in B.M. Trost (Ed.), Comprehensive Organic Synthesis, vol. 8, Pergamon Press, Oxford, 1991, p. 703.

[15] Reviews, see: (a) K. Burgess, M.J. Ohlmeyer, Chem. Rev. 91 (1991) 1179;

(b) I. Beletskaya, A. Pelter, Tetrahedron 53 (1997) 4957;

(c) N. Miyaura, in: A. Togni, H. Grützmacher (Eds.), Catalytic Heterofunctionalization (Chapter 1), Wiley-VCH, Chichester, 2001.

[16] Reviews, see: (a) T.B. Marder, N.C. Norman, Top. Catal. 5 (1998) 63;

(b) T. Ishiyama, N. Miyaura, J. Synth. Org. Chem., Jpn. 57 (1999) 503;

(c) T. Ishiyama, N. Miyaura, J. Organomet. Chem. 611 (2000) 392.

[17] T. Ishiyama, K-i. Nishijima , N. Miyaura, A. Suzuki, J. Am. Chem. Soc. 115 (1993) 7219.

[18] A review, see: M. Suginome, Y. Ito, Chem. Rev. 100 (2000) 3221.

[19] A review, see: L.-B. Han, M. Tanaka, Chem. Commun. (1999) 395.

[20] (a) M. Murata, T. Oyama, S. Watanabe, Y. Masuda, J. Org. Chem. 65 (2000) 164

(b) M. Murata, T. Oyama, S. Watanabe, Y. Masuda, Synthesis (2000) 778;

(c) M. Murata, S. Watanabe, Y. Masuda, Tetrahedron Lett. 41 (2000) 5877;

(d) M. Murata, T. Oyama, S. Watanabe, Y. Masuda, Synth. Commun. 32 (2002) 2513.

[21] Reviews, see: (a) A.E. Shilov, G.B. Shul'pin, Chem. Rev. 97 (1997) 2879;

(b) S.S. Stahl, J.A. Labinger, J.E. Bercaw, Angew. Chem., Int. Ed. 37 (1998) 2180

(c) Y. Guari, S. Sabo-Etienne, B. Chaudret, Eur. J. Inorg. Chem. (1999) 1047; 
(d) G. Dyker, Angew. Chem., Int. Ed. 38 (1999) 1698.

[22] P. Nguyen, H.P. Blom, S.A. Westcott, N.J. Taylor, T.B. Marder, J. Am. Chem. Soc. 115 (1993) 9329.

[23] (a) A review, see: J.F. Hartwig, K.M. Waltz, C.N. Muhoro, X. He, O. Eisenstein, R. Bosque, F. Maseras, in: Advances in Boron Chemistry, The Royal Society of Chemistry, Cambridge, 1997, p. 373;

(b) K.M. Waltz, J.F. Hartwig, Science 277 (1997) 211;

(c) K.M. Waltz, C.N. Muhoro, J.F. Hartwig, Organometallics 18 (1999) 3383.

[24] H. Chen, J.F. Hartwig, Angew. Chem., Int. Ed. 38 (1999) 3391.

[25] H. Chen, S. Schlecht, T.C. Semple, J.F. Hartwig, Science 287 (2000) 1995.

[26] X. Wan, X. Wang, Y. Luo, S. Takami, M. Kubo, A. Miyamoto, Organometallics $21(2002) 3703$.

[27] C.N. Iverson, M.R. Smith III, J. Am. Chem. Soc. 121 (1999) 7696.

[28] J.-Y. Cho, M.K. Tse, D. Holmes, R.E. Maleczka Jr, M.R. Smith III, Science 295 (2002) 305 .

[29] Reviews, see: (a) J. Reedijk, in: G. Wilkinson (Ed.), Comprehensive Coordination Chemistry, vol. 2, Pergamon, New York, 1987, p. 73;

(b) A. Togni, L.M. Venanzi, Angew. Chem., Int. Ed. Engl. 33 (1994) 497;

(c) J.-M. Lehn, Supramolecular Chemistry, VCH, Weinheim, 1995.

[30] T. Ishiyama, J. Takagi, K. Ishida, N. Miyaura, N.R. Anastasi, J.F. Hartwig, J. Am. Chem. Soc. 124 (2002) 390.

[31] Reviews, see: (a) G.J. Leigh, R.L. Richards, in: G. Wilkinson, F.G.A. Stone, E.W. Abel (Eds.), Comprehensive Organometallic Chemistry, vol. 5, Pergamon Press, Oxford, 1982, p. 541; 
(b) J.D. Atwood, in: E.W. Abel, F.G.A. Stone, G. Wilkinson (Eds.), Comprehensive Organometallic Chemistry II, vol. 8, Pergamon Press, Oxford, 1995 , p. 303.

[32] C. Rüchardt, H.-D. Beckhaus, Top. Curr. Chem. 130 (1986) 1.

[33] Z. Friedl, H. Hapala, O. Exner, Coll. Czech. Chem. Commun. 44 (1979) 2928.

[34] H. Yamazaki, H. Tamura, M. Sugimoto, H. Sato, S. Sakaki, 49th Symposium on Organometallic Chemistry, Japan, Kobe, September 2002, PA119.

[35] J.J. Li, G.W. Gribble, in: J.E. Baldwin, F.R.S.\&R.M. Williams (Eds.), Tetrahedron Organic Chemistry Series, vol. 20, Pergamon, Amsterdam, 2000.

[36] J. Takagi, K. Sato, J.F. Hartwig, T. Ishiyama, N. Miyaura, Tetrahedron Lett. 43 (2002) 5649.

[37] (a) L. Dong, S.B. Duckett, K.F. Ohman, W.D. Jones, J. Am. Chem. Soc. 114 (1992) 151

(b) T. Morikita, M. Hirano, A. Sasaki, S. Komiya, Inorg. Chim. Acta 291 (1999) 341 ;

(c) S.N. Ringelberg, A. Meetsma, B. Hessen, J.H. Teuben, J. Am Chem. Soc. 121 (1999) 6082.

[38] M.K. Tse, J.-Y. Cho, M.R. Smith III, Org. Lett. 3 (2001) 2831.

[39] (a) J.P. Parakka, J.A. Jeevarajan, A.S. Jeevarajan, L.D. Kispert, M.P. Cava, Adv. Mater. 8 (1996) 54;

(b) T. Remonen, J. Hellberg, J. Slätt, Synth. Met. 101 (1999) 107;

(c) M. Jayakannan, J.L.J. van Dongen, R.A.J. Janssen, Macromolecules 34 (2001) 5386.

[40] T. Ishiyama, J. Takagi, J.F. Hartwig, N. Miyaura, Angew. Chem., Int. Ed. 41 
(2002) 3056.

[41] T. Ishiyama, Y. Nobuta, J.F. Hartwig, N. Miyaura, unpublished results.

[42] J.-Y. Cho, C.N. Iverson, M.R. Smith III. J. Am. Chem. Soc. 122 (2000) 12868.

[43] S. Shimada, A.S. Batsanov, J.A.K. Howard, T.B. Marder, Angew. Chem., Int. Ed. 40 (2001) 2168 .

[44] T. Ishiyama, K. Ishida, J. Takagi, N. Miyaura, Chem. Lett. (2001) 1082.

[45] S. Siegel, in: B.M. Trost (Ed.), Comprehensive Organic Synthesis, vol. 8, Pergamon, Oxford, 1991, p.417. 


$$
\operatorname{pin}_{2} \mathrm{~B}_{2}+\underset{\text { (excess) }}{\mathrm{H}-\mathrm{R}} \stackrel{\begin{array}{l}
\mathrm{Cp}{ }^{*} \operatorname{Re}(\mathrm{CO})_{3} \\
(2.4-5.0 \mathrm{~mol} \%)
\end{array}}{h / / \mathrm{CO} / 25^{\circ} \mathrm{C}} \operatorname{pinB}-\mathrm{R}+\operatorname{pinBH}
$$

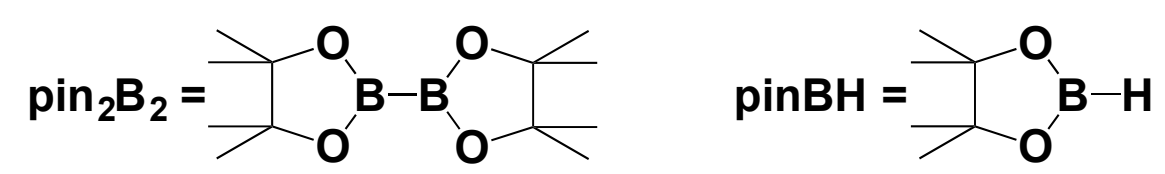

\begin{tabular}{|c|c|c|c|}
\hline & product & yield $/ \%$ & \\
\hline $\operatorname{pinB}-\mathrm{C}_{5} \mathrm{H}_{11}{ }^{n}$ & $95(56 h)$ & pinB $-\mathrm{CH}_{2}\left(c-\mathrm{C}_{6} \mathrm{H}_{11}\right)$ & $75(60 h)$ \\
\hline $\operatorname{pinB}-\left(\mathrm{CH}_{2}\right)_{4} \mathrm{OBu} u^{n}$ & $100(45 \mathrm{~h})$ & $\operatorname{pinB}-\left(\mathrm{CH}_{2}\right)_{2} \mathrm{OBu}{ }^{t}$ & $82(46 h)$ \\
\hline
\end{tabular}

Scheme 1. 


$$
\begin{aligned}
& \left.\operatorname{pin}_{2} \mathrm{~B}_{2}+\mathrm{Cp} \mathrm{pe}^{*}(\mathrm{CO})_{3} \longrightarrow \mathrm{c}^{-\mathrm{C}_{6} \mathrm{H}_{12}} \mathrm{Cp} \mathrm{pe}^{*} \mathrm{ReO}\right)_{2}(\mathrm{Bpin})_{2}
\end{aligned}
$$

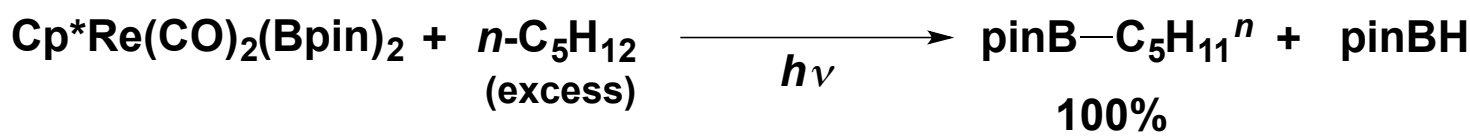

Scheme 2. 


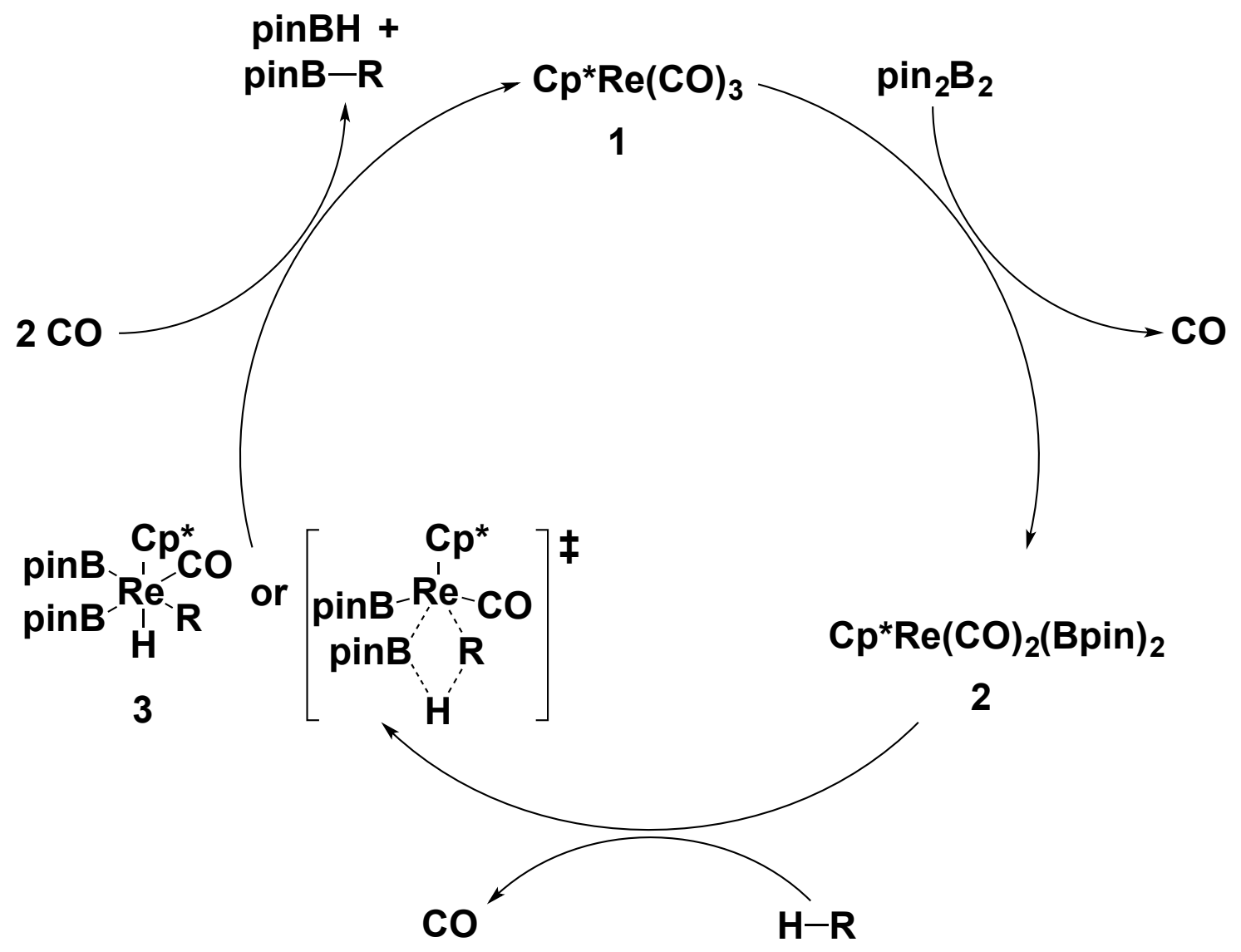

Scheme 3. 


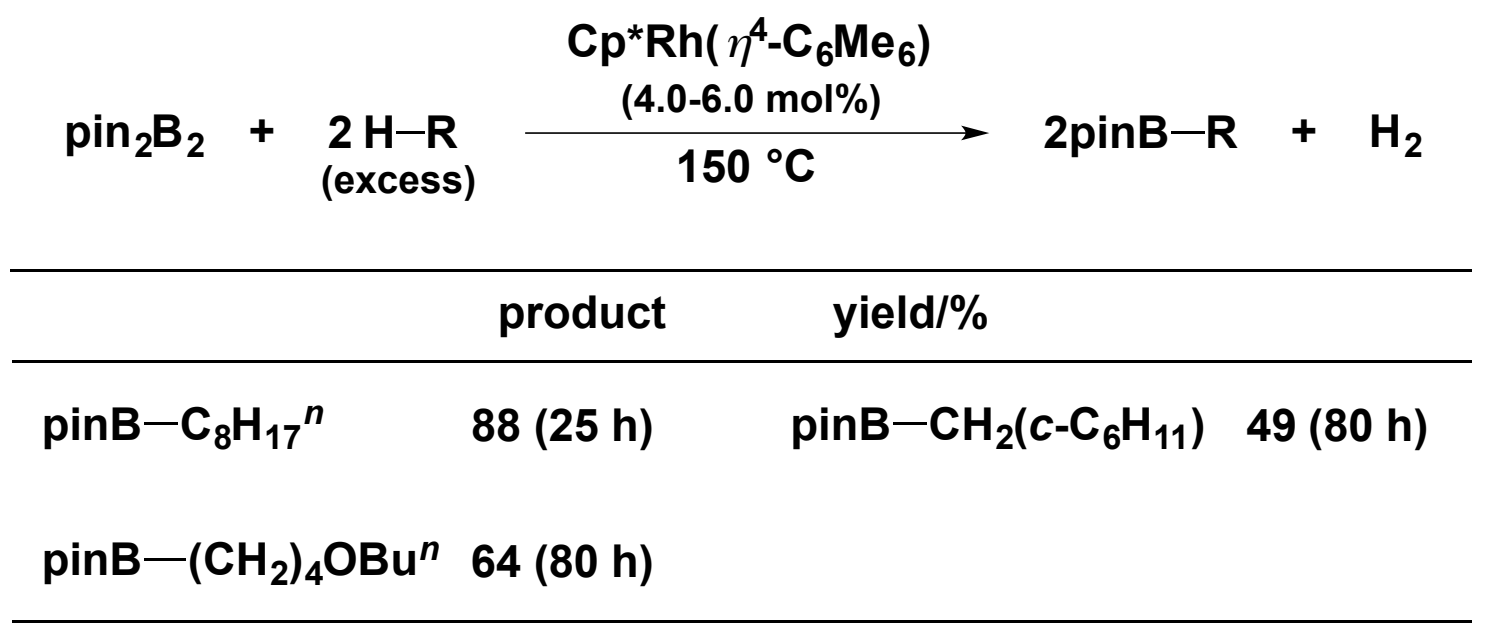

Scheme 4. 


$$
\begin{aligned}
& \mathrm{Cp}^{*} \mathrm{Rh}\left(\eta^{4}-\mathrm{C}_{6} \mathrm{Me}_{6}\right)
\end{aligned}
$$

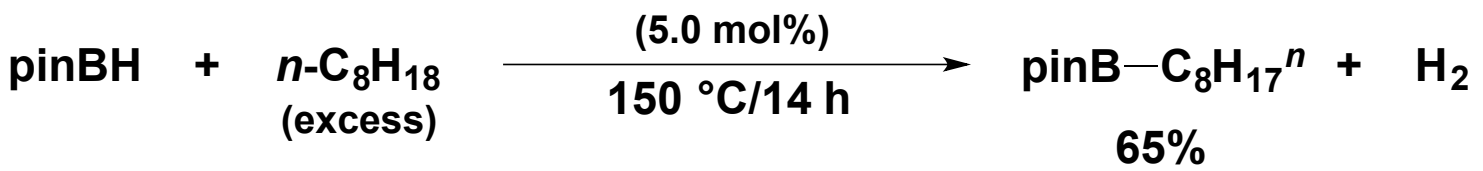

Scheme 5. 


$$
\begin{aligned}
& \operatorname{pin}_{2} \mathrm{~B}_{2}+\mathrm{Cp}{ }^{*} \mathrm{Rh}(\mathrm{H})_{2}\left(\mathrm{SiEt}_{3}\right)_{2} \underset{n-\mathrm{C}_{5} \mathrm{H}_{12} / 150^{\circ} \mathrm{C}}{\longrightarrow} \mathrm{Cp}{ }^{*} \mathrm{Rh}(\mathrm{H})_{2}(\mathrm{Bpin})_{2} \\
& \mathrm{Cp} * \mathrm{Rh}(\mathrm{H})_{2}(\mathrm{Bpin})_{2}+\underset{(\text { excess })}{2 \mathrm{n}-\mathrm{C}_{8} \mathrm{H}_{18}} \longrightarrow \quad 150{ }^{\circ} \mathrm{C} \longrightarrow 2 \mathrm{pinB}-\mathrm{C}_{8} \mathrm{H}_{17}{ }^{n}
\end{aligned}
$$

Scheme 6. 


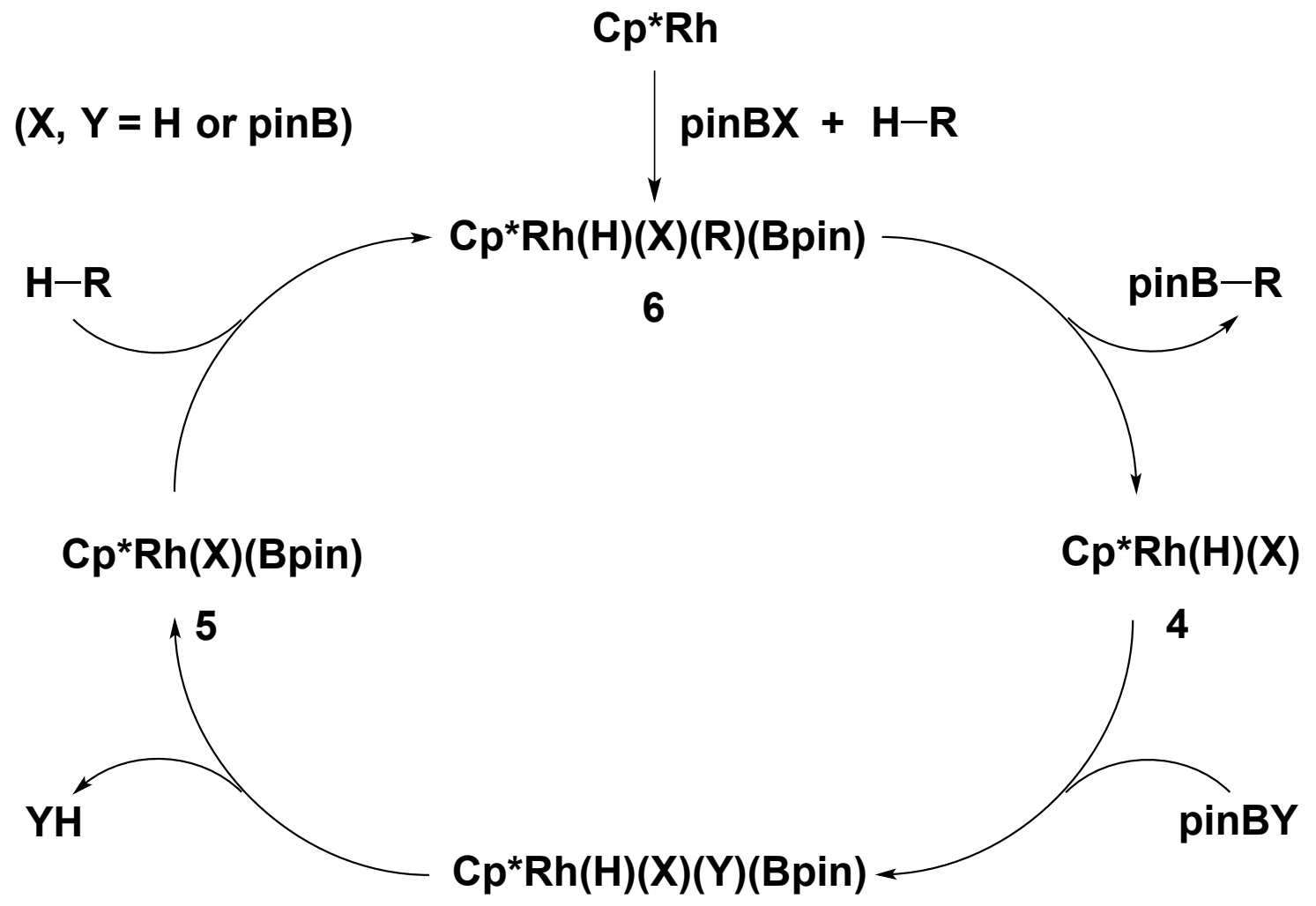

Scheme 7. 


$$
\begin{aligned}
& \mathrm{Cp}^{*} \operatorname{Ir}\left(\mathrm{PMe}_{3}\right)(\mathrm{H})(\mathrm{Bpin})
\end{aligned}
$$

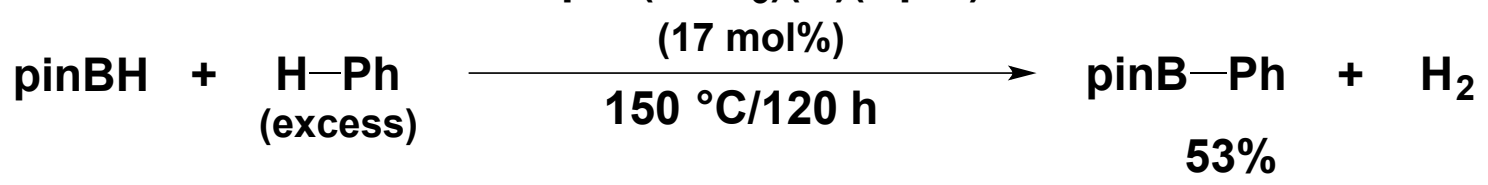

Scheme 8 . 


$$
\begin{aligned}
& \operatorname{Ir}\left(\eta^{5}-\mathrm{C}_{9} \mathrm{H}_{7}\right)(\mathrm{COD})+\mathrm{dmpe} \\
& \operatorname{pinBH}+\underset{(\text { excess })}{\mathrm{H}-\mathrm{Ph}} \stackrel{(0.02 \mathrm{~mol} \%)}{150^{\circ} \mathrm{C} / 61 \mathrm{~h}} \underset{90 \%}{\operatorname{pinB}-\mathrm{Ph}}+\mathrm{H}_{2} \\
& \text { dmpe }=\mathrm{Me}_{2} \mathrm{PCH}_{2} \mathrm{CH}_{2} \mathrm{PMe}_{2}
\end{aligned}
$$

Scheme 9. 


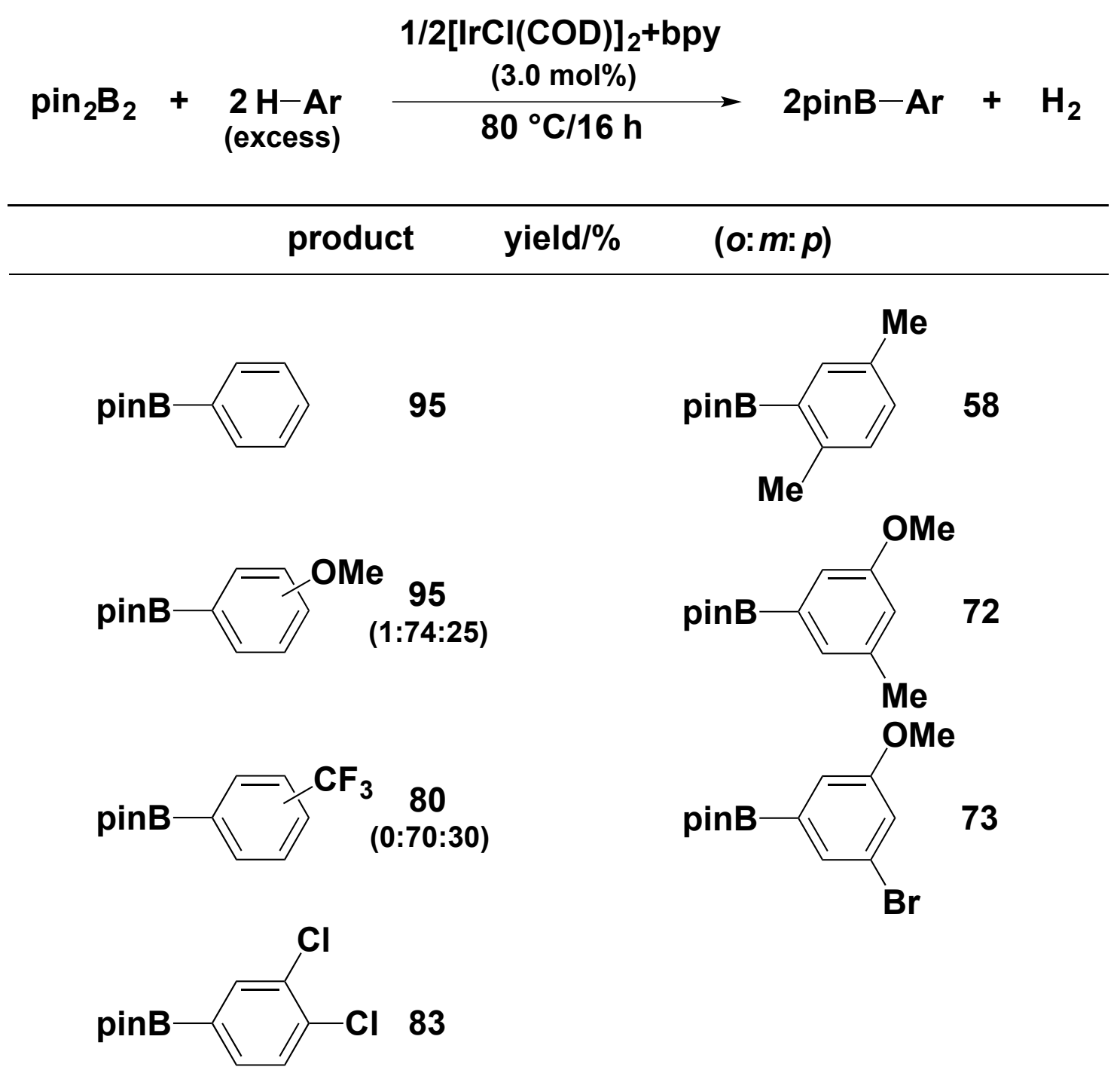

Scheme 10. 


$$
\text { pinBH }+\underset{(\text { excess })}{\mathrm{H}-\mathrm{Ph}} \stackrel{\begin{array}{c}
1 / 2[\mathrm{IrCl}(\mathrm{COD})]_{2}+\text { bpy } \\
(3.0 \mathrm{~mol} \%)
\end{array}}{\mathrm{80}{ }^{\circ} \mathrm{C} / 16 \mathrm{~h}} \underset{\mathrm{pinB}-\mathrm{Ph}}{\mathbf{8 0 \%}}+\mathrm{H}_{2}
$$

Scheme 11. 


$$
\begin{aligned}
& \text { 1/2[IrCl(COE) } \left.{ }_{2}\right]_{2}+d t b p y \\
& \operatorname{pin}_{2} \mathrm{~B}_{2}+\underset{\begin{array}{c}
\text { (excess) } \\
2 \mathrm{H}-\mathrm{Ph}
\end{array}}{2} \quad \underset{80 \%}{2 \mathrm{pinB}-\mathrm{Ph}}+\mathrm{H}_{2} \\
& \text { dtbpy }=\left\langle\sum_{\mathrm{N}}^{\mathrm{t}-\mathrm{Bu}}\right.
\end{aligned}
$$

Scheme 12. 


$$
\begin{aligned}
& \underset{(5.0 \text { eq. })}{2 \operatorname{pin}_{2} \mathrm{~B}_{2}}+1 / 2\left[\operatorname{IrCl}(\mathrm{COE})_{2}\right]_{2}+\text { dtbpy } \underset{50^{\circ} \mathrm{C} / 5 \mathrm{~h}}{\stackrel{\text { mesitylene }}{\longrightarrow}} \operatorname{Ir}(\mathrm{dtbpy})(\mathrm{COE})(\mathrm{Bpin})_{3} \\
& 15 \% \\
& \operatorname{Ir}(\text { dtbpy)(COE)(Bpin) })_{3}+\underset{\text { (excess) }}{3 \mathrm{H}-\mathrm{Ph}} \underset{25^{\circ} \mathrm{C} / \mathrm{a} \text { few min. }}{\longrightarrow} 3 \mathrm{pinB}-\mathrm{Ph} \\
& 80 \%
\end{aligned}
$$

Scheme 13. 


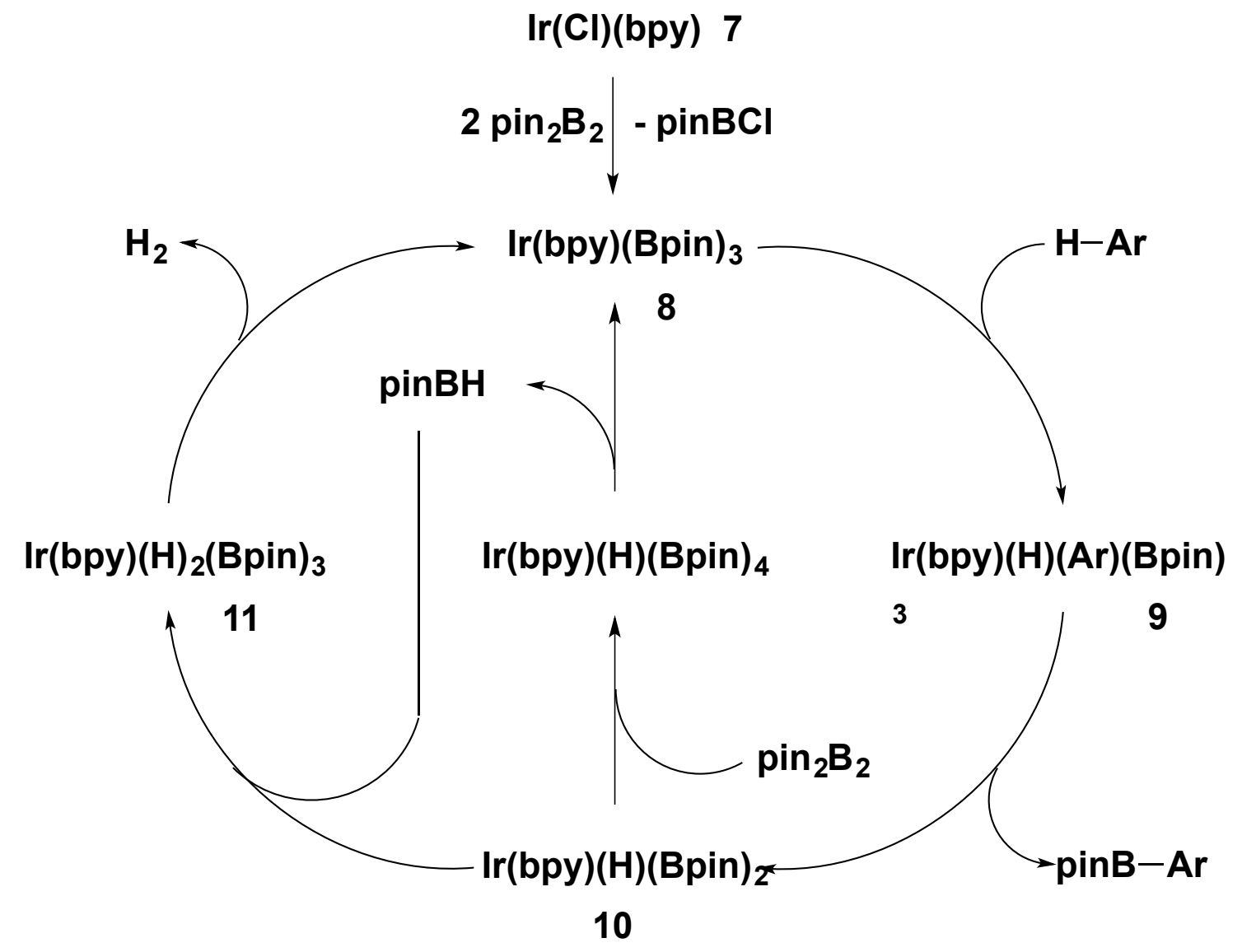

Scheme 14. 


$$
\begin{aligned}
& \text { 1/2[IrCl(COD) }]_{2}+\text { dtbpy } \\
& \operatorname{pin}_{2} B_{2}+\underset{(4-10 \text { eq. })}{2 \mathrm{H}-\mathrm{Ar}} \frac{(3.0 \mathrm{~mol} \%)}{\text { octane } / 80^{\circ} \mathrm{C} / 16 \mathrm{~h}} \text { 2pinB-Ar }+\mathrm{H}_{2}
\end{aligned}
$$<smiles>[Pb]c1ccc[nH]1</smiles>

67<smiles>[PbH]c1ccco1</smiles>

83<smiles>[Pb]c1cccs1</smiles>

83 pinB<smiles>Cc1cc[nH]c1</smiles>
79<smiles>Bc1cc2ccccc2[nH]1</smiles><smiles>[B]Cc1cc2c(o1)C=CCC2</smiles>

pinB<smiles>Cc1cc2ccccc2s1</smiles>
pinB

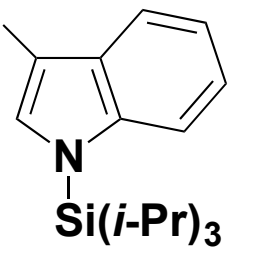

Scheme 15 . 


$$
\begin{aligned}
& 1 / 2[\operatorname{IrCl}(\mathrm{COD})]_{2}+\text { dtbpy } \\
& \operatorname{pin}_{2} B_{2}+\left\langle{ }_{X} \frac{(3.0 \mathrm{~mol} \%)}{\text { octane } / 80^{\circ} \mathrm{C} / 16 \mathrm{~h}} \operatorname{pinB} \longrightarrow{ }_{X} \text { Bpin }+\mathrm{H}_{2}\right. \\
& \text { (1 eq.) } \\
& X=\mathrm{NH}: \mathbf{8 0} \%, X=0: \mathbf{7 1} \%, X=S: 80 \%
\end{aligned}
$$

Scheme 16. 


$$
\operatorname{pin}_{2} \mathrm{~B}_{2}+2 \underbrace{\frac{(3.0 \mathrm{~mol} \%)}{\text { octane } / 100^{\circ} \mathrm{C} / 16 \mathrm{~h}}}_{(2 \text { eq. })} 2 \mathrm{pinB}
$$

Scheme 17. 

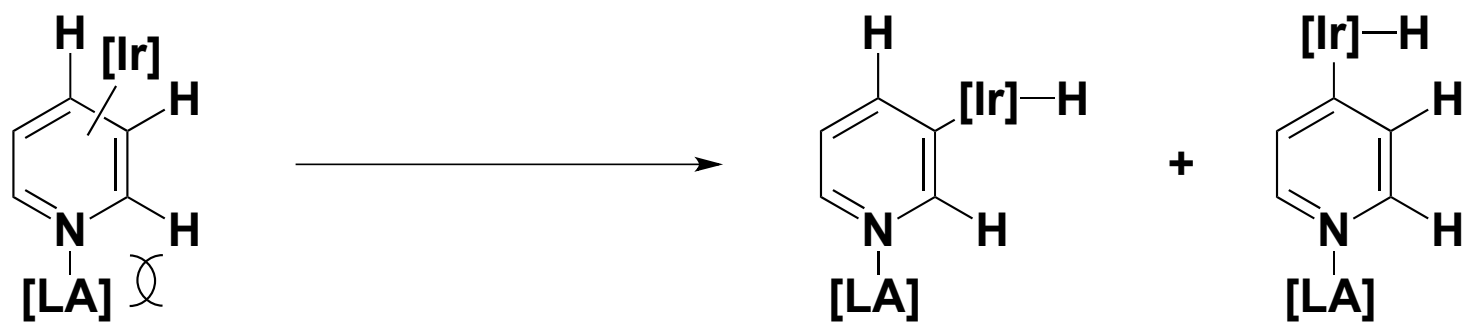

$$
[\operatorname{Ir}]=\operatorname{Ir}(\mathrm{dtbpy})(\text { Bpin })_{3} \quad[\mathrm{LA}]=\operatorname{Ir} \text { or B compounds }
$$

Scheme 18. 


$$
\begin{aligned}
& \underset{(2 \text { eq.) }}{\operatorname{pinBH}} \frac{\operatorname{lr}\left(\eta^{5}-\mathrm{C}_{9} \mathrm{H}_{7}\right)(\mathrm{COD})+\mathrm{dppe}}{c-\mathrm{C}_{6} \mathrm{H}_{12} / 100^{\circ} \mathrm{C} / 4 \mathrm{~h}} \\
& 69 \%
\end{aligned}
$$

Scheme 19. 


$$
\operatorname{pin}_{2} \mathrm{~B}_{2}+\underset{(2 \text { eq. })}{2 \mathrm{H}-\mathrm{Ar}} \stackrel{\begin{array}{c}
1 / 2[\operatorname{Ir}(\mathrm{OMe})(\mathrm{COD})]_{2}+\mathrm{dtbpy} \\
(3.0 \mathrm{~mol} \%)
\end{array}}{\text { hexane } / 25^{\circ} \mathrm{C}} 2 \mathrm{pinB}-\mathrm{Ar}+\mathrm{H}_{2}
$$

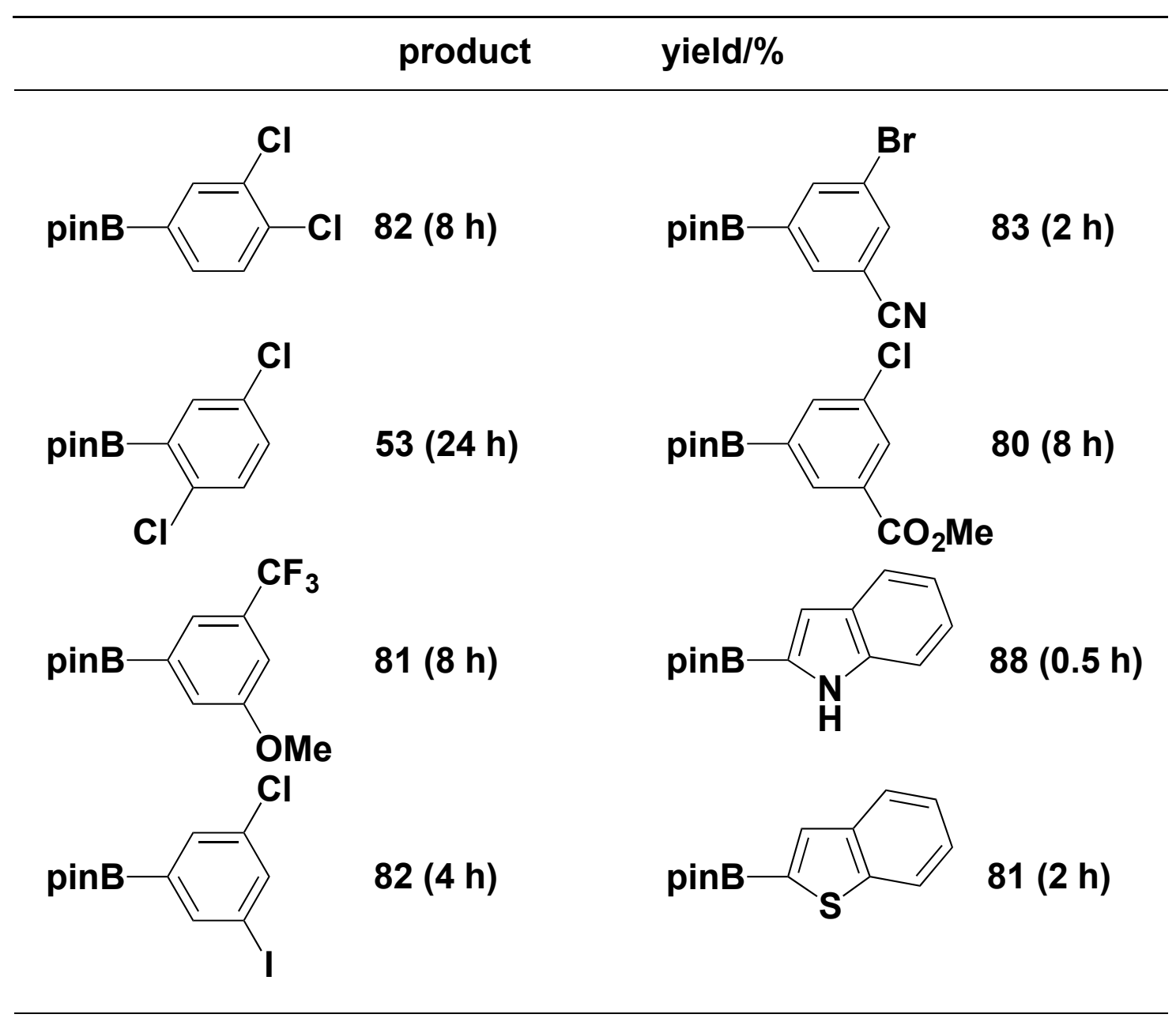

Scheme 20. 


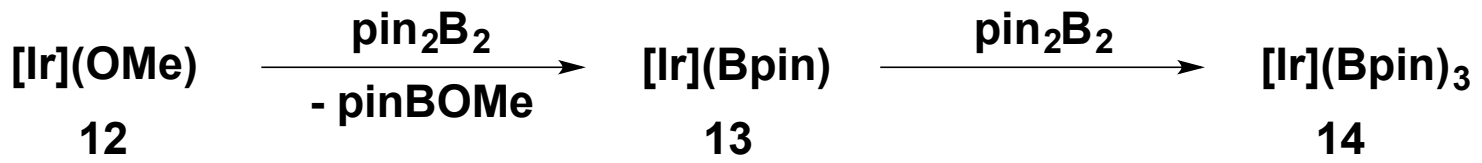

$$
\begin{aligned}
& {[\operatorname{lr}]=\operatorname{Ir}(\mathrm{dtbpy})}
\end{aligned}
$$

Scheme 21. 


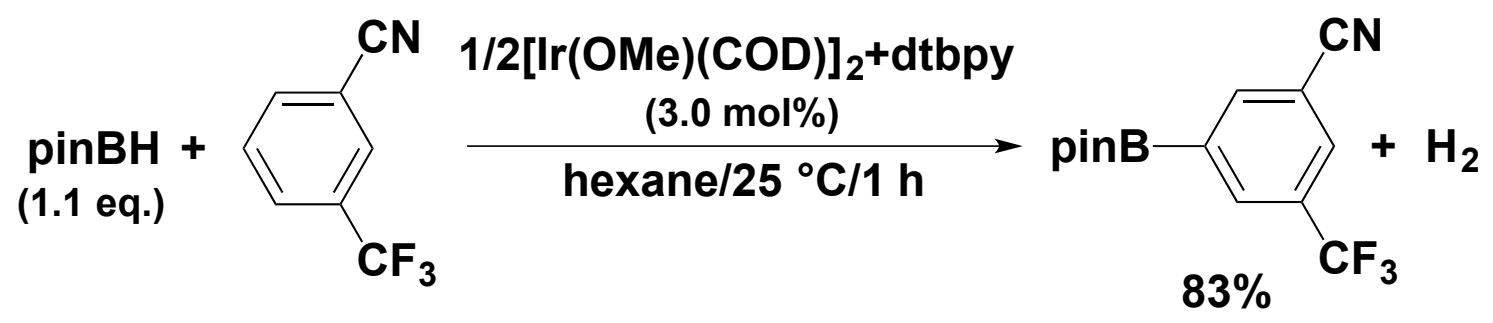

Scheme 22. 


$$
\operatorname{pin}_{2} \mathrm{~B}_{2}+\underset{\text { (excess) }}{\mathrm{H}-\mathrm{Ph}} \stackrel{\underset{\mathrm{Cp}}{\mathrm{C} \operatorname{Re}(\mathrm{CO})_{3}}}{\frac{(10 \mathrm{~mol} \%)}{h v / \mathrm{CO} / 25^{\circ} \mathrm{C} / 36 \mathrm{~h}}} \underset{76 \%}{\operatorname{pinB}-\mathrm{Ph}}+\operatorname{pinBH}
$$

Scheme 23. 


$$
\operatorname{pin}_{2} \mathrm{~B}_{2}+\underset{\text { (excess) }}{2 \mathrm{H}-\mathrm{Ph}} \stackrel{\begin{array}{c}
\mathrm{Cp}{ }^{*} \mathrm{Rh}\left(\eta^{4}-\mathrm{C}_{6} \mathrm{Me}_{6}\right) \\
(0.5 \mathrm{~mol} \%)
\end{array}}{150^{\circ} \mathrm{C} / 45 \mathrm{~h}} \underset{82 \%}{2 \mathrm{pinB}-\mathrm{Ph}}+\mathrm{H}_{2}
$$

Scheme 24 . 


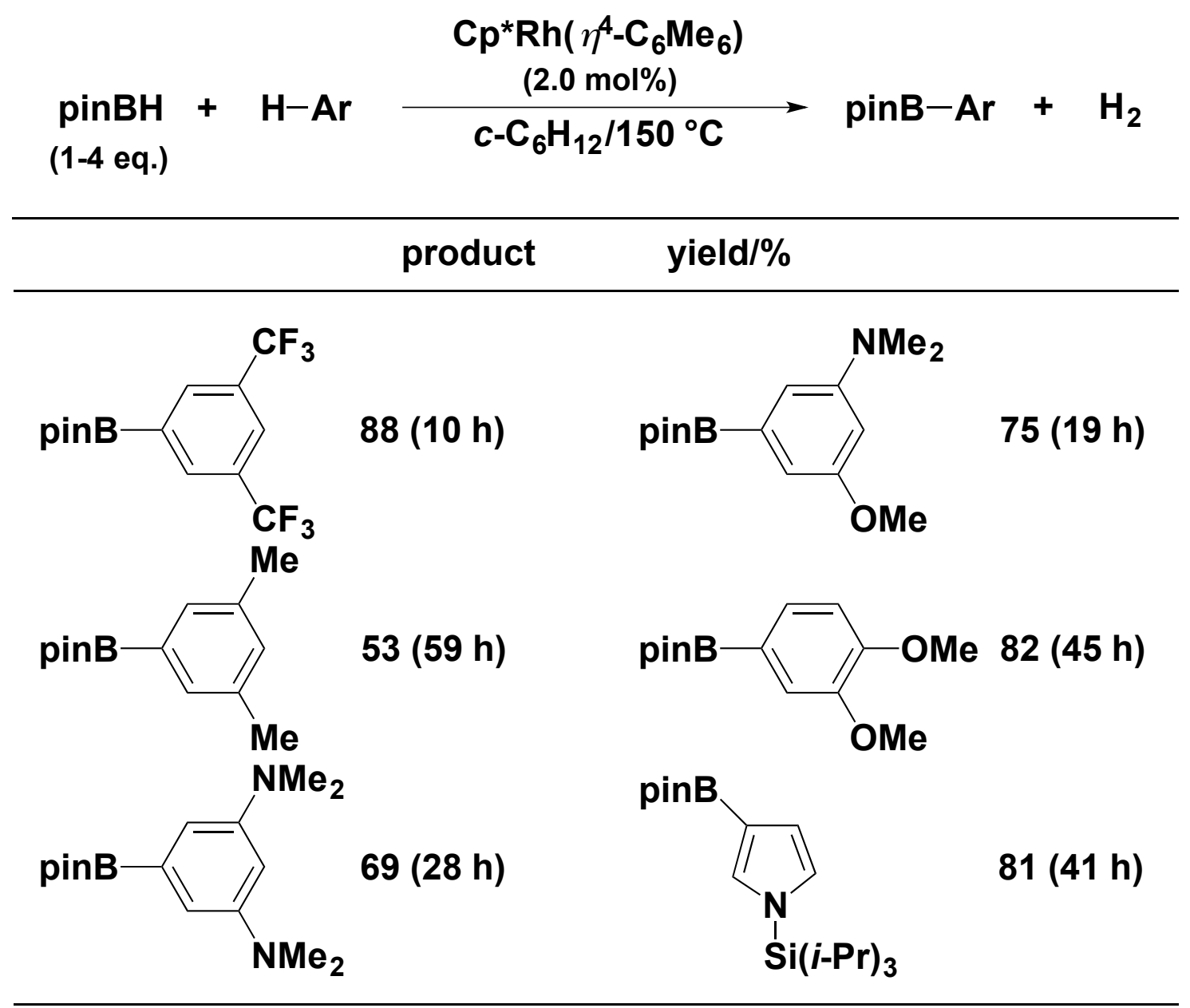

Scheme 25. 


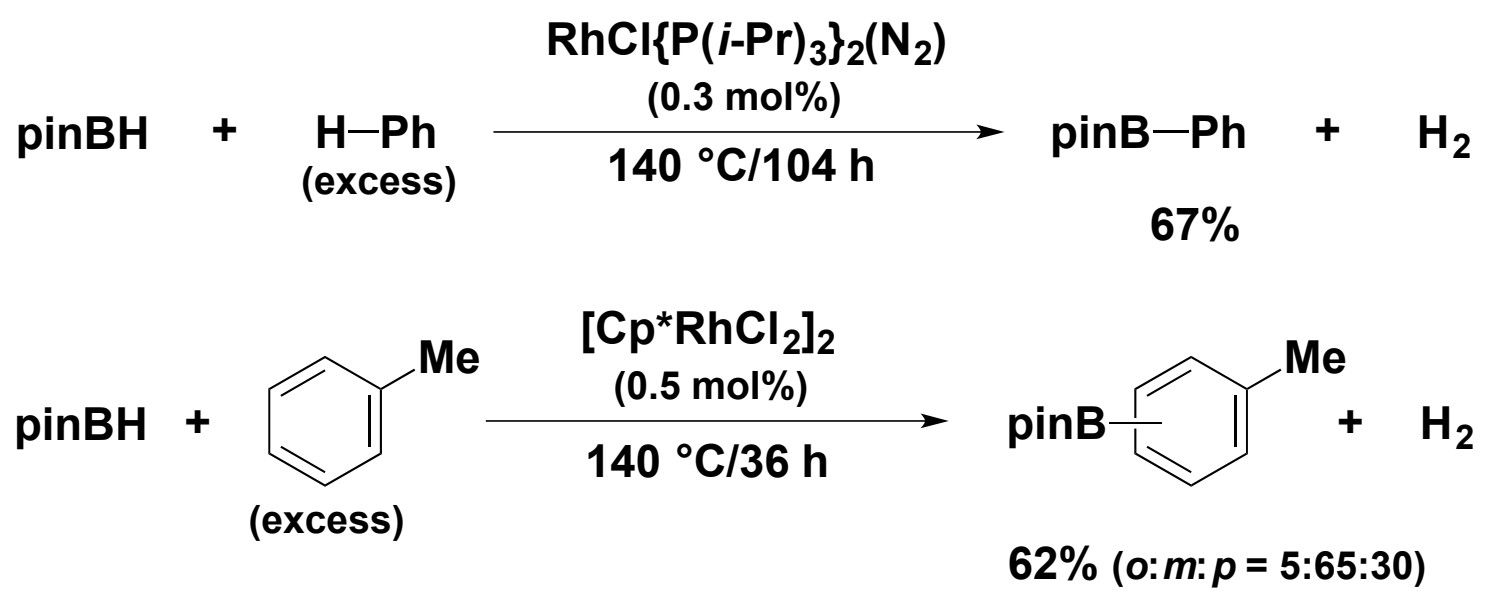

Scheme 26. 


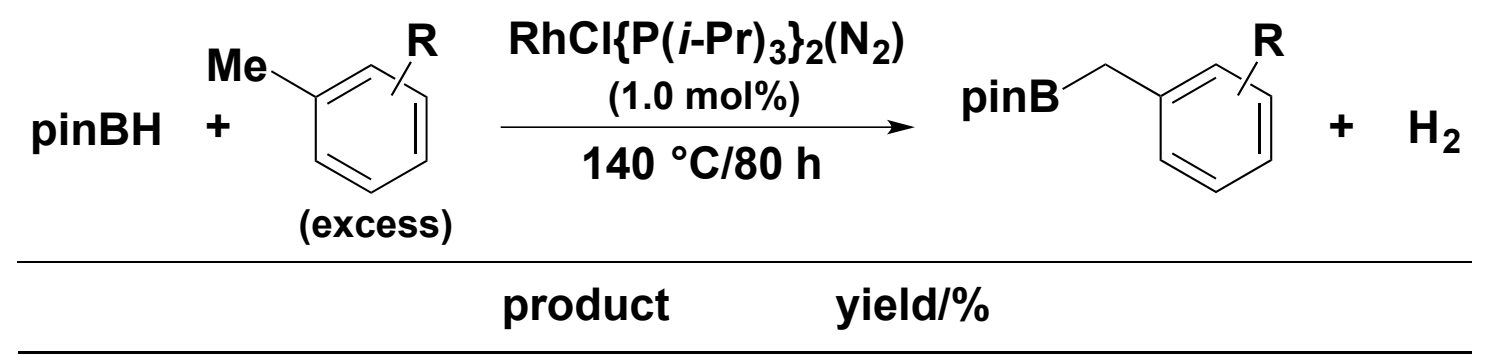

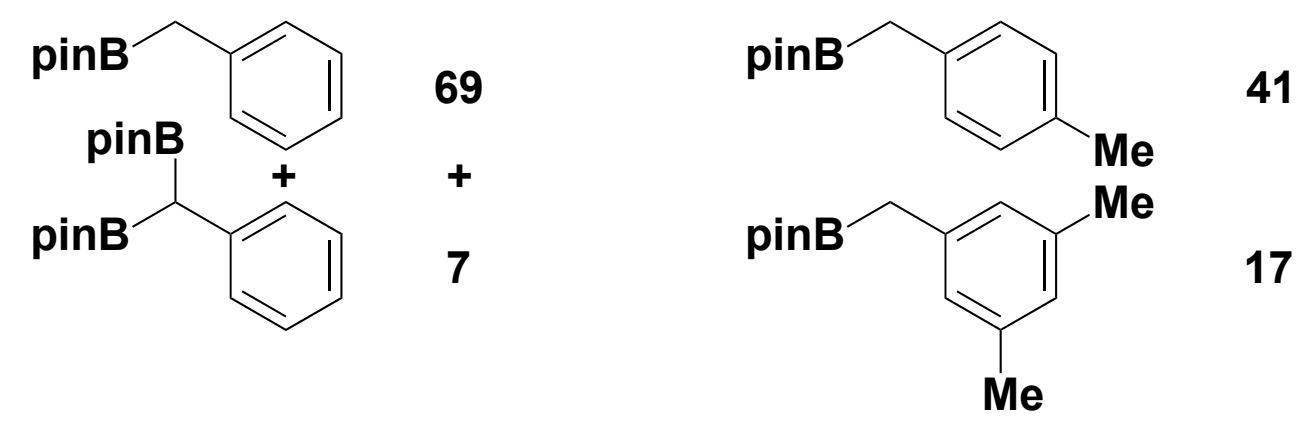

Scheme 27. 


pin $\mathrm{B}_{2}+2$

Scheme 28. 


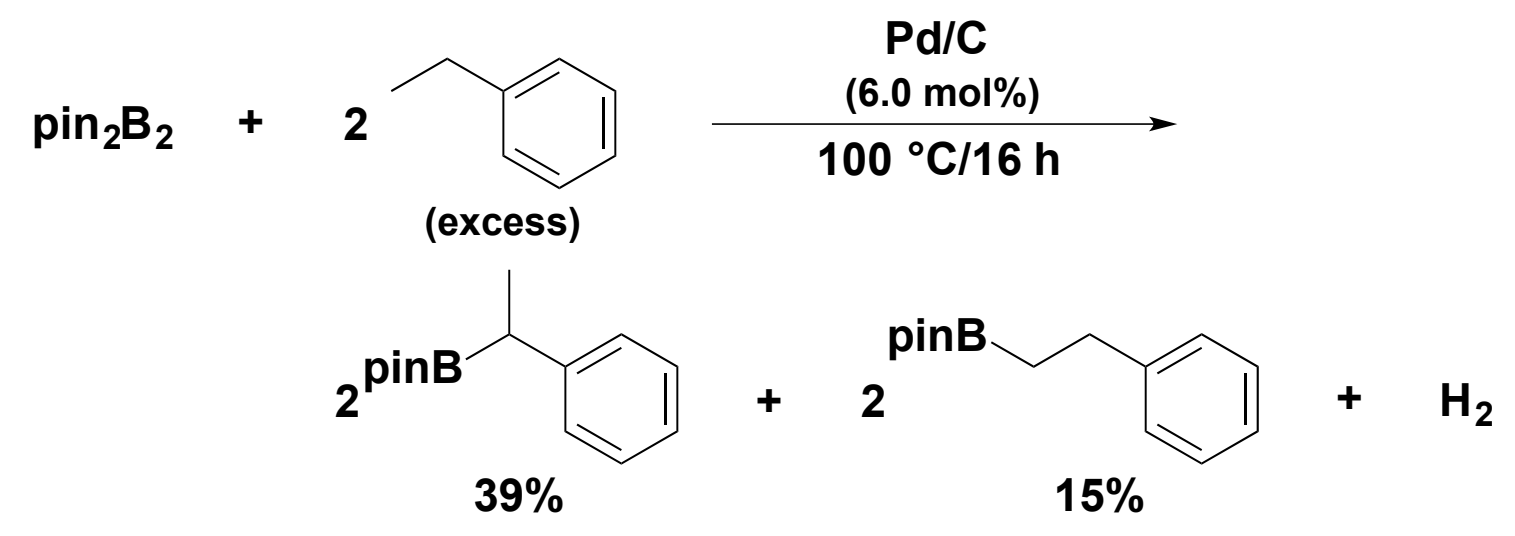

Scheme 29. 


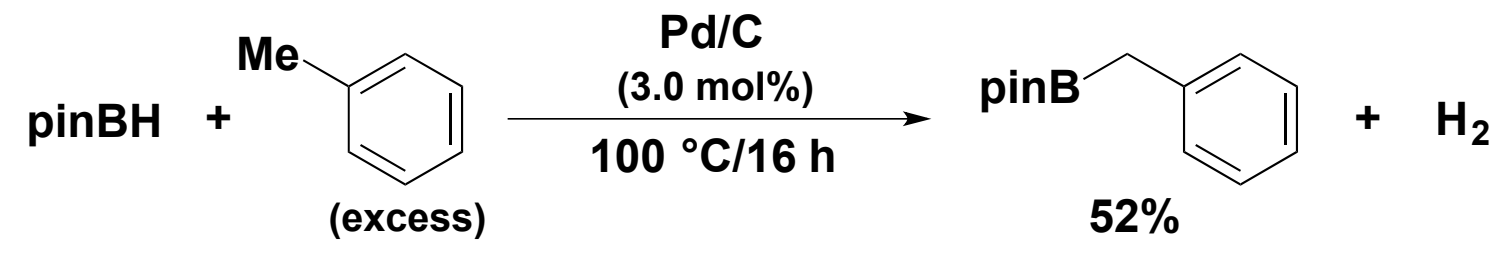

Scheme 30. 